\title{
Effects of Various Steam Flooding Injection Patterns and Steam Quality on Oil Recovery Factor
}

\author{
Indri Kusumastuti ${ }^{1}$, Tomi Erfando ${ }^{1}$, Fiki Hidayat ${ }^{1}$ \\ ${ }^{1}$ Universitas Islam Riau
}

\begin{abstract}
The main principle of steam flooding is to reduce the oil viscosity using hot steam that is injected into the reservoir. In the field implementation there are several injection patterns that can be applied for steam flooding. This research aims to determine the effect of several injection patterns and steam quality on oil recovery factor. Therefore, it can be known the injection pattern and steam quality are right to obtain the best recovery factor. Analysis was carried out on injection patterns including five-spots, inverted five-spots, seven-spots, inverted seven-spots, nine-spots, and inverted nine-spots. The variations in the steam quality used are 50\%, 70\% and 90\%. The simulation model a 3-dimensional cartesian with grid block size 5x5x5 on CMG STARS. The temperature of steam flooding process for all of the scenario was set at $450{ }^{\circ} \mathrm{F}$, with the injection pressure of $500 \mathrm{psi}$, and 1,000 bbl/day of injection rate. Of all the scenarios tested the best results were in the inverted seven spot pattern with steam quality 0.9 , where recovery factor was $35,1 \%$ and total cumulative production was $269,397 \mathrm{bbl}$.
\end{abstract}

Keywords: Steam flooding, pattern, steam quality, recovery factor

Corresponding Author: tomierfando@eng.uir.ac.id

\section{INTRODUCTION}

Heavy oil are oil that have a high viscosity value with a low API degree making it difficult to produce in the conventional way. Some new eor methods continue to be developed to increase production in the field having heavy oil or also high paraffin content including low salinity water (Fiki Hidayat, Erfando, \& Maulana, 2018), electromagnetic heating, etc. One of the best methods that has been proven to overcome this problem is using steam injection (F Hidayat \& Abdurrahman, 2018). The biggest steam flooding project in the world is located in Indonesia, precisely in Riau Province which is the largest oil producer in the country (Erfando \& Herawati, 2017). Selection of an injection pattern is essential so that the injected fluid is not lost on the proper target of production aging, and get the sweeping pattern as efficiently as possible. Injection well patterns should also be considered in considering the use of steam types. The injection well pattern can maximize the efficiency of the ignition with uniform heat transfer resulting in a good injection response of the reservoir (Arisyi, Irham, \& Prakoso, 2015).

In this study, it will examine the effect of the injection pattern and combine with some steam quality to see which injection patterns and steam quality percentages produce the best recovery factor and cummulative production. In this study used to compare six injection well pattern that is five-spot, inverted five-spot, seven-spot, inverted sevenspot, nine-spot, and inverted nine-spot in increasing of recovery factor and oil production cumulative. The injection pattern to be used is a five-spot, inverted five-spot, seven-spot, inverted seven-spot, nine-spot, and inverted ninespot, while for steam quality it consists of 0.5 (50\% steam and 50\% water ), 0.7 (70\% steam and 30\% water), 0.9 (90\% steam and $10 \%$ water).

\section{METHODOLOGY}

This research use CMG STAR to simulate the steam flooding process into the reservoir model. Table 1 fluid and rock properties are taken from Ferizal et al. (2013). The reservoir model in this simulation is a cartesian grid with dimensions of $5 \times 5 \times 5$ where permeability is $300 \mathrm{mD}, 300 \mathrm{mD}$, and $150 \mathrm{mD}$ respectively (Fig. 1). The uniform viscosity value on each grid layer is $500 \mathrm{cp}$. A total of 18 scenarios that will be applied to the reservoir model, the result of a combination of injection patterns and steam quality. Each scenario is injected for 1095 days. The temperature of steam flooding process for all of the scenario was set at $450{ }^{\circ} \mathrm{F}$, with the injection pressure of 500 psi, and 1,000 bbl/day of injection rate. 


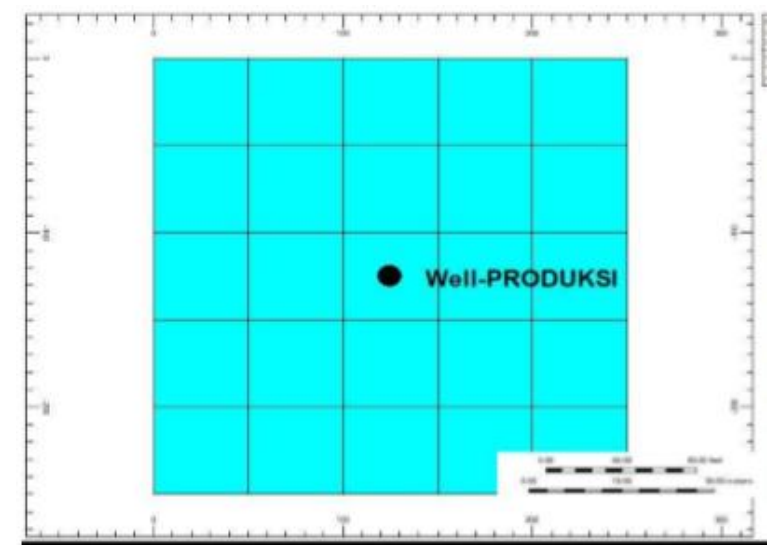

Fig. 1. Cartesian Model 2 D

Table 1. Fluid dan Rock Properties

\begin{tabular}{llll}
\hline Paremeter & Value & Parameter & Value \\
\hline Viscosity & $500 \mathrm{cp}$ & Bubble Point Pressure & $161 \mathrm{psig}$ \\
\hline Oil Density & $0.99 \mathrm{lb} / \mathrm{cuft}$ & Porosity & 0.25 \\
\hline Water Density & $62.4 \mathrm{lb} / \mathrm{cuft}$ & Vertical Permeability & $300 \mathrm{mD}$ \\
\hline API Gravity & $11^{0} \mathrm{API}$ & Horizontal Permeability & $300 \mathrm{mD}$ \\
\hline Formation Volume Factor & $1.021 \mathrm{bbl} / \mathrm{STB}$ & Compressibility & $5 \mathrm{E}-6 \mathrm{psi}-1$ \\
\hline Type of Oil & Heavy Oil & Wettability & Oil Wet
\end{tabular}

\section{RESULTS AND DISCUSSION}

Figure $2 \mathrm{a}$ shows the show from the recovery factor for five-spot meanwhile figure $2 \mathrm{~b}$ shows the oil cumulative production.

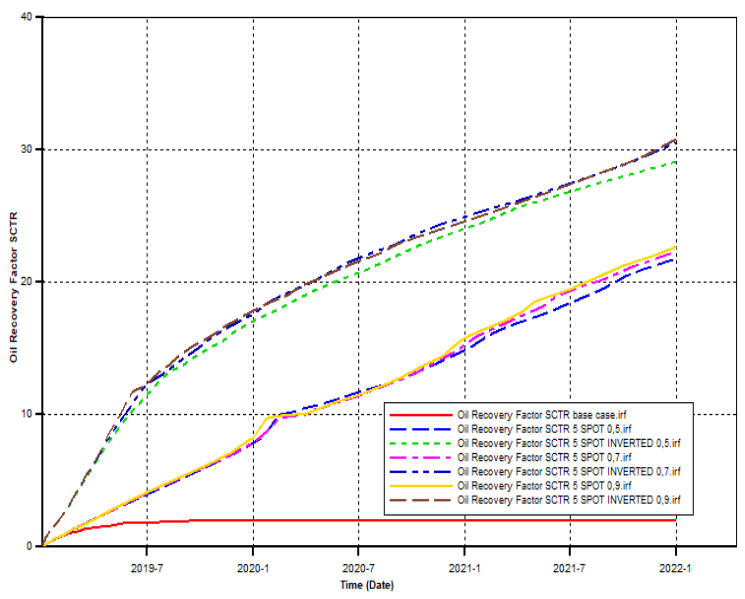

(a)

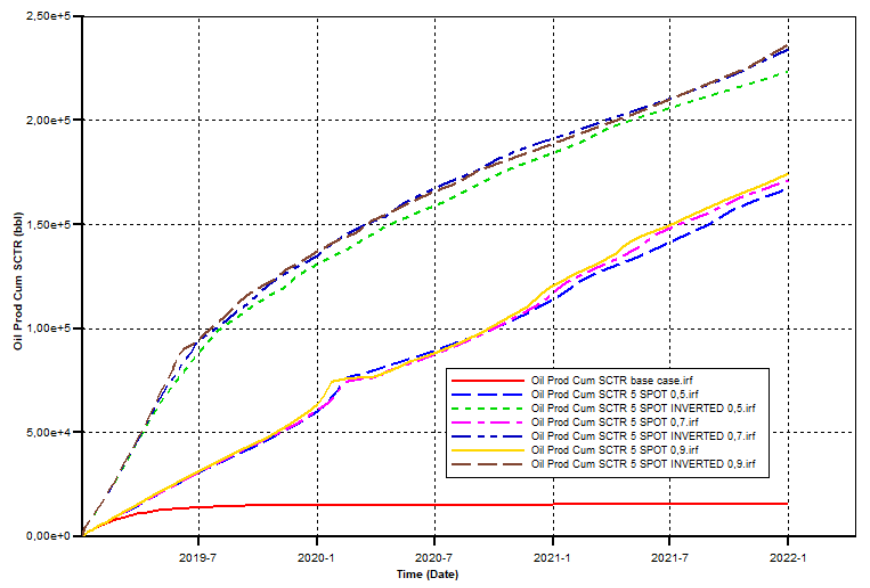

(b)

Fig. 2. Recovery factor (a) and cumulative production (b) for five-spot and inverted five-spot pattern

From the figure 2 it can be stated the cumulative production and recovery factor in the steam flooding injection pattern of five-spot inverted are higher than the five-spot pattern in all steam qualities. This result is also similar to the research conducted by Srochviksit \& Maneeintr (2016). The quality steam of 0,9 gives the highest recovery 
factor of $30.8 \%$. To compare the incremental recovery oil values between the three scenarios of quality steam can show in Table 2 . The higher the steam quality will produce higher cumulative production, therefore the recovery factor obtained is also higher (Erfando, Rita, \& Marliaty, 2017).

Table 2. Comparing oil recovery factor cumulative production in five-spot pattern and inverted five-spot pattern

\begin{tabular}{lccc}
\hline Injection Well Pattern & Quality Steam & Recovery Factor & Cumulative Production \\
\hline Five-Spot & 0.5 & $21.8 \%$ & $167180 \mathrm{bbl}$ \\
\cline { 2 - 4 } & 0.7 & $22.1 \%$ & $171385 \mathrm{bbl}$ \\
\cline { 2 - 4 } & 0.9 & $22.7 \%$ & $174336 \mathrm{bbl}$ \\
\hline Inverted Five-Spot & 0.5 & $29.1 \%$ & $223452 \mathrm{bbl}$ \\
\cline { 2 - 4 } & 0.7 & $30.5 \%$ & $234130 \mathrm{bbl}$ \\
\cline { 2 - 4 } & 0.9 & $30.8 \%$ & $236300 \mathrm{bbl}$ \\
\hline
\end{tabular}

Chu (1993) states that the normal seven-spot has lower recovery factor then inverted seven-spot. The results of seven-spot and inverted seven-spot analysis resulted in the highest incremental recovery factor increase in the seven-spot inverted pattern with quality steam 0,9 of $37.1 \%$ with a cumulative production of $284661 \mathrm{bbl}$ (figure 3 and table 3). Below we will show the analysis of seven-spot and inverted seven-spot pattern. In the inverted seven spot pattern the distribution of steam is more evenly distributed across all production wells and also the temperature in that area is also higher than the other patterns. This explanation is supported by research conducted by Fuaadi, Pearce, \& Gael (1991).

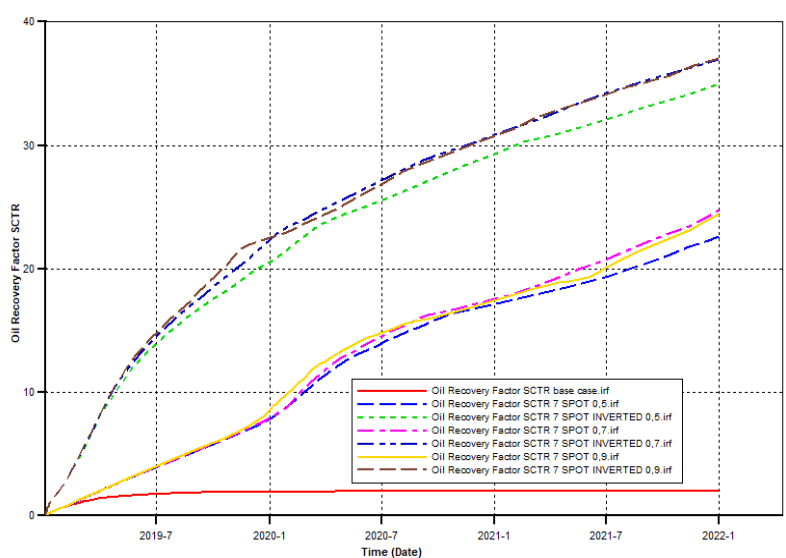

(a)

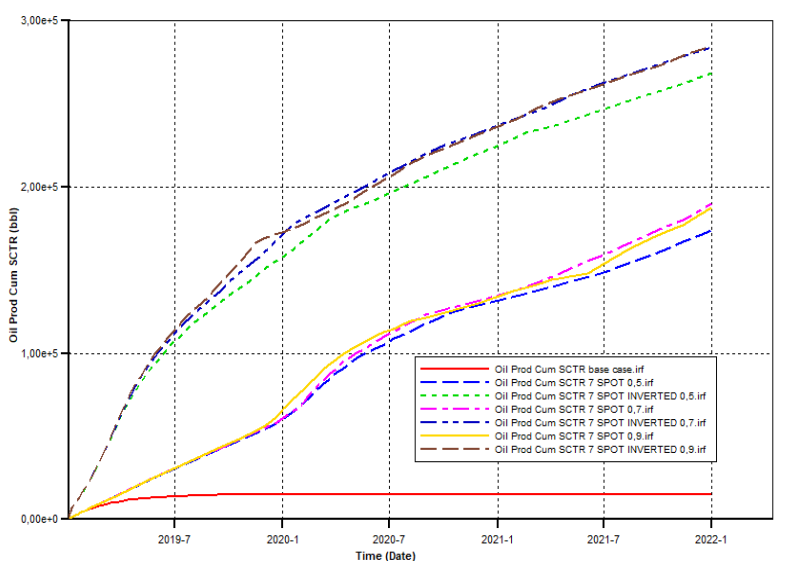

(b)

Fig. 3. Recovery factor (a) and cumulative production (b) for seven-spot and inverted seven-spot pattern

Table 3 Comparing oil recovery factor cumulative production in seven-spot pattern and inverted seven-spot pattern

\begin{tabular}{lccc}
\hline Injection Well Pattern & Quality Steam & Recovery Factor & Cumulative Production \\
\hline Seven-Spot & 0.5 & $22.6 \%$ & $173851 \mathrm{bbl}$ \\
\cline { 2 - 4 } & 0.7 & $24.8 \%$ & $190112 \mathrm{bbl}$ \\
\cline { 2 - 4 } & 0.9 & $24.5 \%$ & $187840 \mathrm{bbl}$ \\
\hline Inverted Seven-Spot & 0.5 & $35.0 \%$ & $268696 \mathrm{bbl}$ \\
\cline { 2 - 4 } & 0.7 & $37.0 \%$ & $284109 \mathrm{bbl}$ \\
\cline { 2 - 4 } & 0.9 & $37.1 \%$ & $284661 \mathrm{bbl}$ \\
\hline
\end{tabular}


Results of analysis with nine-spot and inverted nine-spot patterns resulted in the highest incremental recovery factor increment in inverted nine-spot pattern with a quality steam of 0,9 of $35.9 \%$ with a cumulative production of $276095 \mathrm{bbl}$ (table 4). Below figure 4 we will show the analysis of nine-spot and inverted nine-spot pattern.

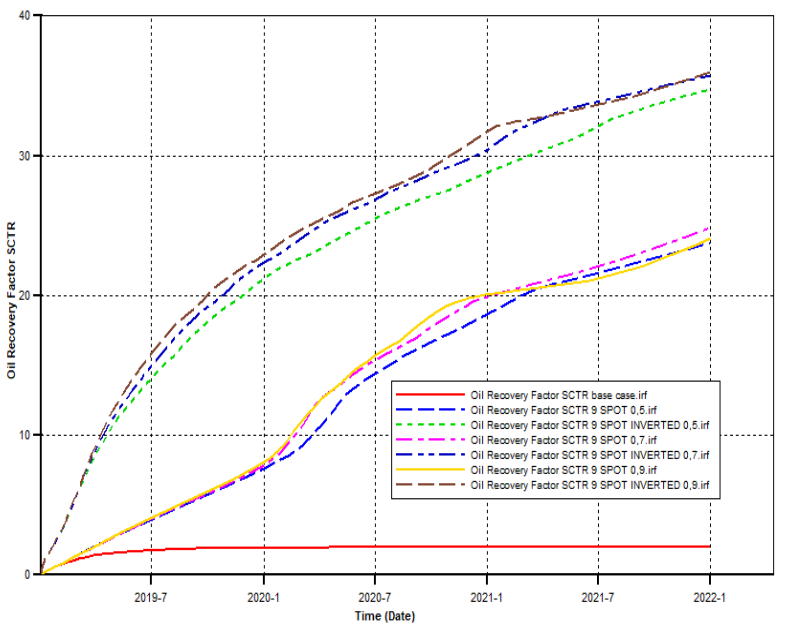

(a)

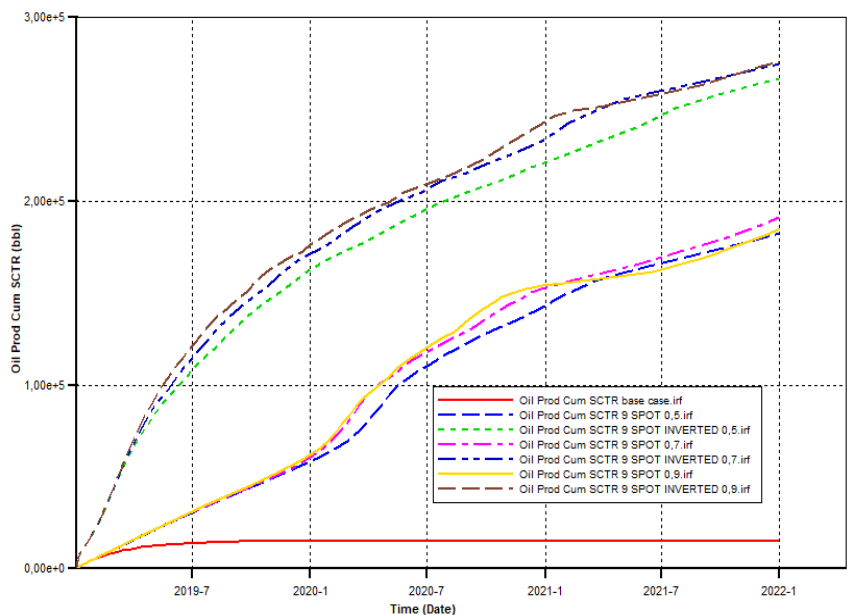

(b)

Fig. 4. Recovery factor (a) and cumulative production (b) for nine-spot and inverted nine-spot pattern

Table 4. Comparing oil recovery factor cumulative production in nine-spot pattern and inverted nine-spot pattern

\begin{tabular}{lccc}
\hline Injection Well Pattern & Quality Steam & Recovery Factor & Cumulative Production \\
\hline Nine-Spot & 0.5 & $23.8 \%$ & $182563 \mathrm{bbl}$ \\
\cline { 2 - 4 } & 0.7 & $24.9 \%$ & $191060 \mathrm{bbl}$ \\
\cline { 2 - 4 } & 0.9 & $24.1 \%$ & $185181 \mathrm{bbl}$ \\
\hline Inverted Nine-Spot & 0.5 & $34.7 \%$ & $266935 \mathrm{bbl}$ \\
\cline { 2 - 4 } & 0.7 & $35.8 \%$ & $274758 \mathrm{bbl}$ \\
& 0.9 & $35.9 \%$ & $276095 \mathrm{bbl}$
\end{tabular}

All of the above results show that the inverted five-spot injection pattern, inverted seven-spot, and inverted ninespot produce cumulative production and recovery factor which are better than the normal shape of each pattern. This is caused by the inverted heat pattern that is scattered throughout the surrounding production wells. Meanwhile in the normal pattern of injection wells which are only focused on one production well does not provide a significant recovery increase. The difference between inverted and normal patterns ranges $7.3 \%$ and $12.4 \%$.

\section{Analysis Effect of Quality Steam in Increasing Reservoir Temperature}

Oil recovery will increase with the increase of steam injection quality, but at the temperature sensitivity it is seen that gain increase as the steam temperature rises and falls back aftter temperature exceeds $500^{\circ} \mathrm{F}$ (Salam, 2017). The success of continuous steamflooding injection in inverted seven-spot injection well pattern in addition to the precision of the quality steam is also due to the successful heat transfer from the steam injection in raising the temperature of the reservoir. So as to change the viscosity of heavy oil to a lighter oil viscosity.

Thermal phenomena do not occur evenly throughout the volume of steamflooding reservoirs. Certain regions are affected thermal from other regions. Thus steamflooding process usually produces several different temperature and fluid flow regions. The picture will be show how temperature distribution in injection well pattern inverted five-spot, inverted seven-spot, and inverted nine-spot. 
Average temperature of initial reservoir or the base case pattern average temperature value of reservoirs is $110^{\circ}$ F. in figure $5 \mathrm{a}$, figure $5 \mathrm{~b}$, and figure $5 \mathrm{c}$ displays the temperature distribution in reservoir due to influence of distribution from quality steam. Table 5 below will be show the results of temperature distribution from well pattern inverted five-spot, inverted seven-spot, and inverted nine-spot.

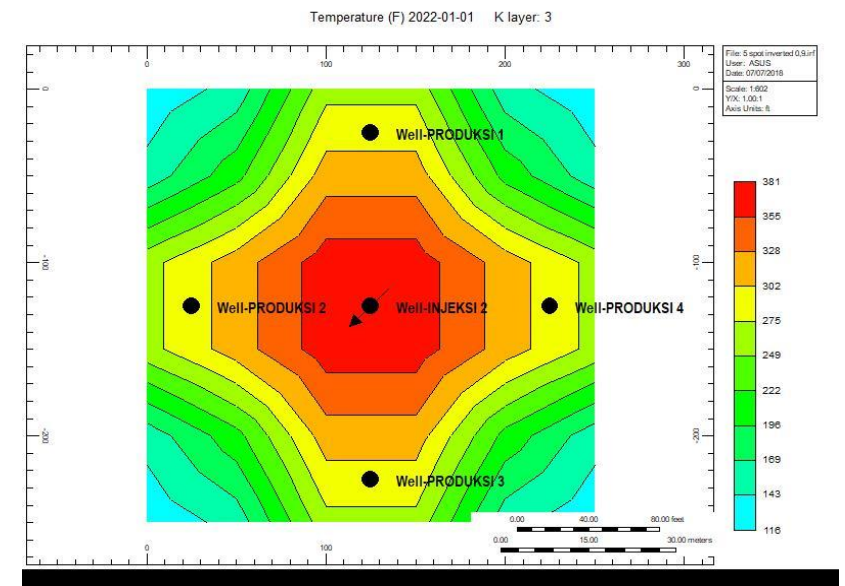

(a)

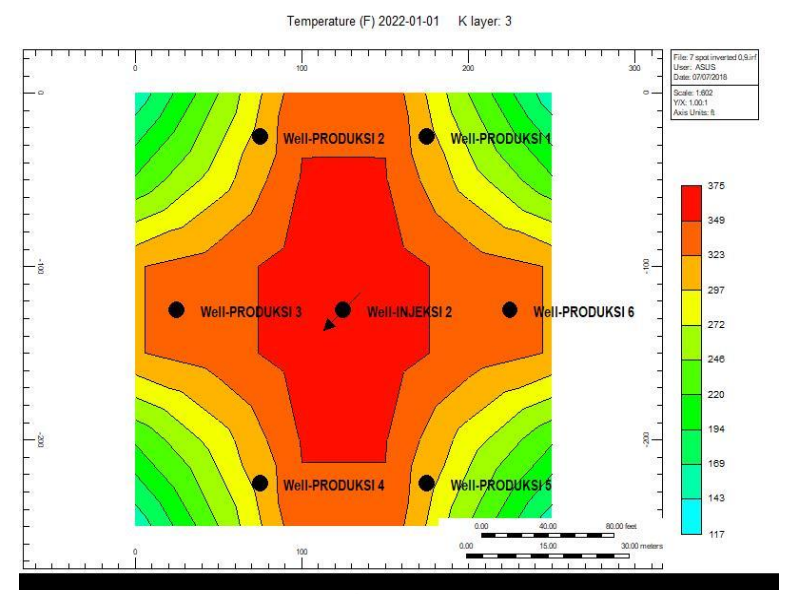

(b)

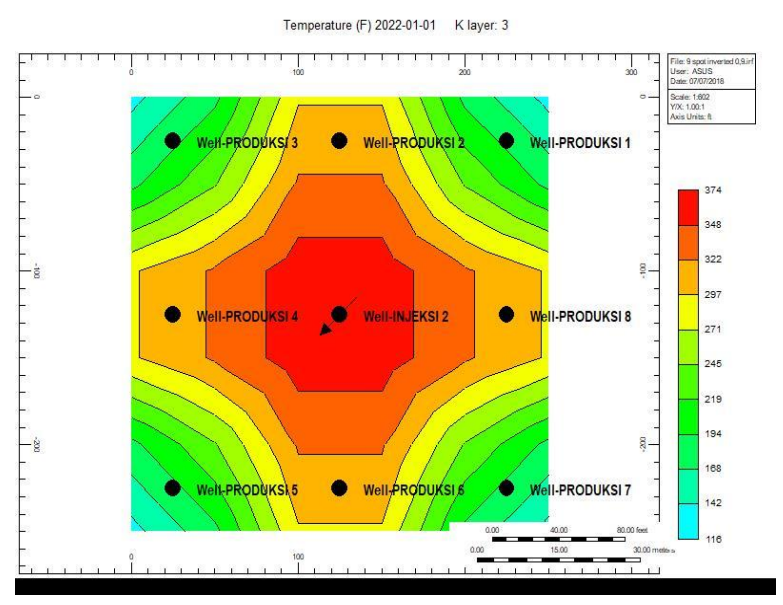

(c)

Figure 5 Effect of quality steam on inverted five-spot (a) inverted nine-seven spot (b) and inverted nine-spot (c) with quality steam 0,9

Table 5 Average Temperature at the end of steamflooding period until 2022

\begin{tabular}{lcccc}
\hline \multicolumn{1}{c}{ Injection Well Pattern } & \multicolumn{3}{c}{ Average Temperature } \\
\cline { 2 - 5 } & 2019 & 2020 & 2021 & 2022 \\
\hline Inverted Five-Spot (Quality Steam 0,9) & $163 \mathrm{~F}$ & $197 \mathrm{~F}$ & $237 \mathrm{~F}$ & $271 \mathrm{~F}$ \\
\hline Inverted Seven-Spot (Quality Steam 0,9) & $176 \mathrm{~F}$ & $216 \mathrm{~F}$ & $265 \mathrm{~F}$ & $299 \mathrm{~F}$ \\
\hline Inverted Nine-Spot (Quality Steam 0,9) & $178 \mathrm{~F}$ & $243 \mathrm{~F}$ & $265 \mathrm{~F}$ & $286 \mathrm{~F}$
\end{tabular}

The concept of steam flooding will increase the temperature in the reservoir (Temizel, Purwar, Dursun, \& Hancioglu, 2013). In the inverted pattern produces a recovery factor, it will be discussed further changes in temperature in the reservoir in the pattern. Within 3 years the highest injection occurred in the inverted seven-spot 
injection pattern. Within 3 years the highest injection occurred in the inverted seven-spot injection pattern. There is an increase of $123^{\circ} \mathrm{F}$ while in the inverted five-spot pattern and inverted nine-spot increase is only $108^{\circ} \mathrm{F}$. in figure $5 \mathrm{~b}$, shows the distribution of temperature is more evenly distributed across all production wells than the other two inverted patterns. This is also the cause of recovery factor and the highest cumulative production in the seven-spot inverted pattern is $37.1 \%$ and $276095 \mathrm{bbl}$.

\section{CONCLUSION}

Based on six injection patterns and three variations of quality of steam, the best recovery factor and cumulative production were obtained from the inverted seven-spot injection pattern. Furthermore, when viewed from the change in temperature after injection, this also increased the highest temperature in the inverted seven-spot pattern.

\section{ACKNOWLEDGEMENTS}

The authors gratefully acknowledgement support from Computer Modelling Group (CMG) and Simulation Laboratory Petroleum Engineering Universitas Islam Riau

\section{REFERENCES}

Arisyi, Irham, \& Prakoso, S. (2015). Pengaruh Penentuan Pilot Design Terhadap Efisiensi Penyapuan Pada Kegiatan Waterflooding Di Lapangan Aa Lapisan M-31. In Seminar Nasional Cendekiawan 2015 (pp. 158167).

Chu, C. (1993). Optimal Choice of Completion Intervals for Injectors and Producers in Steamfloods. SPE International Thermal Operations Symposium. Bakersfield, California: Society of Petroleum Engineers. https://doi.org/10.2118/25787-MS

Erfando, T., \& Herawati, I. (2017). Analysis of Petroleum Downstream Industry Potential in Riau Province. Journal of Geoscience, Engineering, Environment, and Technology, 2(2), 178. https://doi.org/10.24273/jgeet.2017.2.2.304

Erfando, T., Rita, N., \& Marliaty, T. (2017). Optimasi Laju Injeksi Pada Sumur Kandidat Convert to Injection (CTI) di Area X Lapangan Y. Journal of Earth Energy Engineering; Vol 6 No 2 (2017): OCTOBER. https://doi.org/10.22549/jeee.v6i2.992

Ferizal, F. H., Netzhanova, A. A., Lee, J., Bae, W., Am, S., \& Gunadi, T. A. (2013). Revitalizing Indonesia's Potential for Oil Production: The Study of Electromagnetically Heated Gravel Packs for Steam-produced Heavy Oil Reservoirs. SPE Heavy Oil Conference-Canada. Calgary, Alberta, Canada: Society of Petroleum Engineers. https://doi.org/10.2118/165508-MS

Fuaadi, I. M., Pearce, J. C., \& Gael, B. T. (1991). Evaluation of Steam-Injection Designs for the Duri Steamflood Project. SPE Asia-Pacific Conference. Perth. Australia: Society of Petroleum Engineers. https://doi.org/10.2118/22995-MS

Hidayat, F., \& Abdurrahman, M. (2018). A Prospective Method to Increase Oil Recovery in Waxy-Shallow Reservoir. IOP Conference Series: Materials Science and Engineering, 306, 12040. https://doi.org/10.1088/1757-899x/306/1/012040

Hidayat, F., Erfando, T., \& Maulana, B. F. (2018). Spontaneous Imbibition Test of Low Salinity Injection at Low Saline Waxy Crude Carbonate Fiki. Journal Eart Energy Engineering, 7(2), 14-22. https://doi.org/10.25299/jeee.2018.vol7(2).2215

Salam, A. H. (2017). Optimalisasi Produksi pada Operasi Steamflood dengan Menggunakan Injeksi Kualitas Uap Model Gelombang. Jurnal Sains Dan Teknologi Industri; Vol 15, No 1 (2017): DESEMBER 2017.

Srochviksit, S., \& Maneeintr, K. (2016). Simulation on heavy oil production from steam-flooding. In MATEC web of conferences (Vol. 68, p. 7002). EDP Sciences. 
Temizel, C., Purwar, S., Dursun, S., \& Hancioglu, B. (2013). Understanding the Key Parameters in Optimization of Steamfloods in Heavy Oil Fields with Application on SPE Comparative Solution Project. SPE Kuwait Oil and Gas Show and Conference. Kuwait City, Kuwait: Society of Petroleum Engineers. https://doi.org/10.2118/167341-MS 